\title{
建築構造用高強度鋼材 H-SA700A を用いた乾式組立材の 弾性横座屈耐力評価式に関する一考察 \\ ON ELASTIC LATERAL BUCKLING STRENGTH FORMULA FOR WELD-FREE BUILT-UP MEMBER MADE OF H-SA700A HIGH-STRENGTH STEEL
}

\author{
玉井宏章*, 松尾 彰**, 山西央朗***, 高松 隆夫**** \\ Hiroyuki TAMAI, Akira MATSUO, Teruaki YAMANISHI \\ and Takao TAKAMATSU
}

\begin{abstract}
Researchers, including the authors of this paper, are striving to develop main members of built-up structures using $780 \mathrm{~N} / \mathrm{mm}^{2}$ high-strength steel for a new built-up structural system that prevents buildings from collapsing or being damaged by a severe earthquake (JMA seismic intensity 6.5) and enables rapid functional recovery.

The authors propose a weld-free built-up structural member that has a cross section of two channel steel members made of high-strength steel stitched together with bolts. This member has high strength, so that its cross section can be small and it becomes slender, thus creating the possibility of buckling problems.

In a previous study, an elastic lateral-torsional buckling test was carried out on such members, and a simple flexural strength formula was presented for practical design. The value calculated by this fromula is safe compared with the lateral-torsional buckling test results.

However, it cannot represent the influence of bolt pitch and is not accurate enough for design.

The sectional shape of the member is changed in the longitudial direction, so a new torsion constatnt calculation equation is required.

This paper presents a precise calculation equation for torsion and warping constants of this member and derives an elastic lateral buckling strength formula. The accuracy and efficiency of this formula are demonstrated by a comparative study using lateral-torsional buckling tests and axial buckling and twisting test results.
\end{abstract}

Keywords : Built-up member, High strength steel, Lateral buckling, Bolt pitch 組立材，高強度鋼，横座屈，綴り材間隔

\section{1. はじめに}

激震 ( 計測震度 6.5) に対しても建築物は倒壊，損壊せず，さらに， 速やかな機能復旧を可能とする新しい建築構造システムとして，建 築物の主要部材に $780 \mathrm{~N} / \mathrm{mm}^{2}$ 級以上の高強度鋼材を使用した主要部材 の開発が，著者等を含めた研究者により行われている ${ }^{1-9)}$.

材料の高強度化を比較的簡単にするには，接合時に溶接による熱 影響を極力生じさせないことが重要となる。本研究では，溶接を用 いない部材として，新規に高強度鋼でできた 2 本の溝形鋼の背を合 わせてボルト接合した断面をもつ乾式組立材を対象とする.

この乾式組立材は，材が高強度のため作用応力度が高くなること， かつ，断面がスレンダーになることから普通鋼の部材と比べて，座 屈現象が問題になると考えられる.
そこで文献 1,2 では，この高強度鋼組立材について等曲げ，片曲げ 下の弾性横座屈載荷試験を行い, 組立材の横座屈性状を検討した。

設計の便を考えて，簡単な弾性横座屈耐力評価式を示し，評価式 が, 安全側の評価となることを示した。しかしながら, 簡易評価式は, 綴り材間隔の変化による耐力変化特性を精度よく表現できないこと， 綴りによって材軸方向に断面形状が变化するため， サンブナンねじ り定数や曲げねじり定数の算定方法が，問題となることが明らかと なった。

そこで, 本報ではより精度の高い組立材の断面定数の算定式, 弾 性横座屈の算定式を誘導し，前述の等曲げ，片曲げ下の実験結果と 比較して, 提案式の妥当性を示す。

\footnotetext{
本論文の一部は既に文献 3 に報告している。

* 広島工業大学工学部建築工学科 准教授 · 博士 (工学)

**広島大学大学院建築学専攻 教授. 工博

*** 広島工業大学高性能構造システム開発研究センター 研究員 ·博士 (工学)

$* * * *$ 広島工業大学工学部建築工学科 教授 $\cdot \mathrm{Ph} . \mathrm{D}$.
}

Assoc. Prof., Faculty of Eng., Hiroshima Institute of Technology, Dr. Eng.

Prof., Graduate School of Eng., Hiroshima University, Dr. Eng.

Researcher, Center for High Performance Structure of Building, Hiroshima Institute of

Technology, Dr. Eng.

Prof., Faculty of Eng., Hiroshima Institute of Technology, Ph. D. 


\section{2. 高強度鋼組立材}

提案する高強度鋼組立材の概要を Fig.1 に示す。普通鋼の約 2 倍の 強度を有する H-SA700A 鋼 (板厚 $9 \mathrm{~mm}$ ) の鋼板を冷間プレス成形して 溝形鋼を作成し，断面を背合わせに綴り材 (H-SA700A，板厚 $9 \mathrm{~mm})$ を挟んで，等ピッチで 1 列 2 本の超高力ボルト F14TM16 で組立てた ものである。

Table 1 に, H-SA700A 鋼材の JIS5 号試験片の素材特性の一例を示す.

\section{3．弾性横座屈曲げ耐力算定式の誘導}

\section{1 弾性座屈耐力相関関係式}

文献 10,11 を参考に組立材の $M_{e}-N_{e}$ 弾性座屈耐力相関関係式（座屈固 有方程式）を導出した後，弾性横座屈耐力評価式を誘導する。ほぼ $\mathrm{H}$ 形をした組立断面部材の曲げとねじりの釣り合い方程式を簡略化 して表すことを考える。曲げねじりに伴う，そりの効果は上下フラ ンジが支配的であることから，上下フランジ図心位置で横変形を横 座屈変形として取り扱えば，簡単化できる ${ }^{11)}$ ばかりでなく，中心圧 縮座屈と同様な耐力評価式とすることができる.

中心圧縮座屈と同様な式であれば，Timoshenko が文献 10 で示して いるような組立材の弱軸曲げ剛性低下の影響を容易に取り入れられ る。これらの理由から，上下フランジ位置に断面を集約させるモデ ル化を採用する (Fig.2 参照)。ここで，簡単化のため，横変形と㸚 じり角以外の変形は生じないものとする．初期軸力の影響を GreenLagrange の歪を採用して考慮し高次項を省略することにすれば，仮 想仕事の原理から次式が得られる。

$$
\begin{array}{r}
\int_{0}^{\ell_{b}}\left[E \cdot I_{T} \cdot u_{T}^{\prime \prime} \cdot \delta u_{T}^{\prime \prime}+E \cdot I_{B} \cdot u_{B}^{\prime \prime} \cdot \delta u_{B}^{\prime \prime}+G \cdot J \cdot\left(\frac{u_{T}{ }^{\prime}-u_{B}{ }^{\prime}}{d}\right) \cdot\left(\frac{\delta u_{T}{ }^{\prime}-\delta u_{B}{ }^{\prime}}{d}\right)\right. \\
\left.-N_{T}^{(0)} \cdot u_{T}{ }^{\prime} \cdot \delta u_{T}{ }^{\prime}-N_{B}^{(0)} \cdot u_{B}{ }^{\prime} \cdot \delta u_{B}{ }^{\prime}\right] d z-\left.P_{T} \cdot \delta u_{T}\right|_{z=\ell_{b}}-\left.P_{B} \cdot \delta u_{B}\right|_{z=\ell_{b}}=0
\end{array}
$$

ここで, $E \cdot I_{T}, E \cdot I_{B}$ は上下フランジの構面外曲げ剛性, $G \cdot J$ は サンブナンねじり剛性, $N_{T}^{(0)}, N_{B}^{(0)}$ は, 上下フランジの初期圧縮軸力, $u_{T}, u_{B}$ は，上下フランジの横変形， $d$ は上下フランジの板厚中心間距 離， $P_{T}, P_{B}$ は，上下フランジのせん断外力である. $\delta()$ は仮想変位 を（）'はZ方向の偏微分を示す.

この式の停留条件から，部材内部の釣り合い方程式は次の 2 式と なる。

$$
\begin{aligned}
& \left(\delta u_{T} \text { について }\right) \\
& {\left[E \cdot I_{T} \cdot u_{T}{ }^{\prime \prime}\right]^{\prime}-\left[G \cdot J \cdot\left(\frac{u_{T}{ }^{\prime}-u_{B}{ }^{\prime}}{d^{2}}\right)\right]^{\prime}+\left[N_{T}^{(0)} \cdot u_{T}{ }^{\prime}\right]^{\prime}=0} \\
& \left(\delta u_{B} \text { について }\right) \\
& {\left[E \cdot I_{B} \cdot u_{B}{ }^{\prime \prime}\right]-\left[G \cdot J \cdot\left(\frac{u_{B}{ }^{\prime}-u_{T}{ }^{\prime}}{d^{2}}\right)\right]^{\prime}+\left[N_{B}^{(0)} \cdot u_{B}{ }^{\prime}\right]^{\prime}=0}
\end{aligned}
$$

ちなみに組立材全体の初期合応力 $M^{(0)}, N^{(0)}$ と $N_{T}^{(0)}, N_{B}^{(0)}$ の関係は, 次式で表される $\left(N^{(0)}\right.$ は圧縮を正としている. $)$.

$$
N_{T}^{(0)}=\frac{N^{(0)}}{2}+\frac{M^{(0)}}{d} \quad, \quad N_{B}^{(0)}=\frac{N^{(0)}}{2}-\frac{M^{(0)}}{d}
$$

Timoshenkoによれば，組立材の弱軸曲げ岡性低下に基因する座屈 耐力の低下は，個々の材の曲げ変形を考慮すれば良いことが知られ ている，すなわち，綴りによる弱軸曲げ剛性の低下の影響は，平面
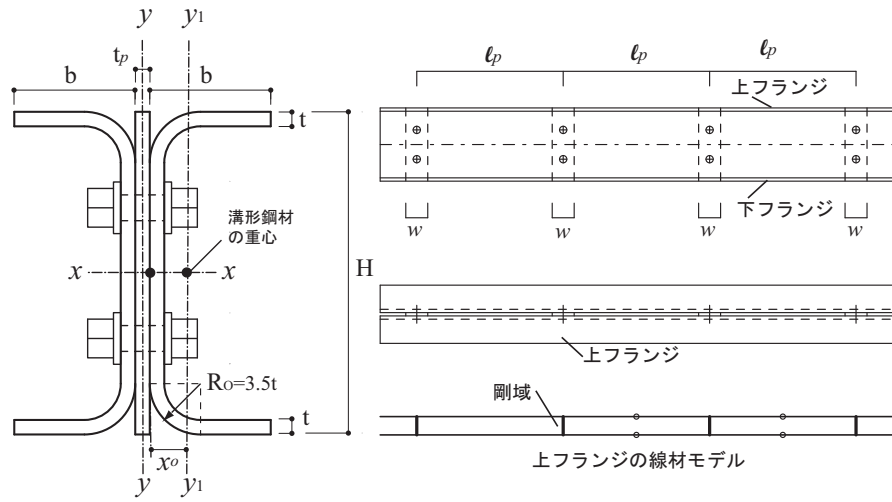

$\mathrm{H}$

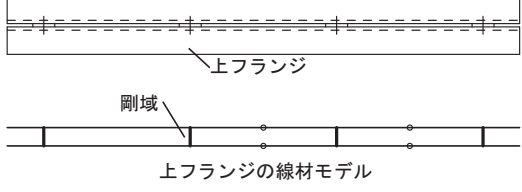

Fig.1 高強度組立材の断面と綴り材の形式

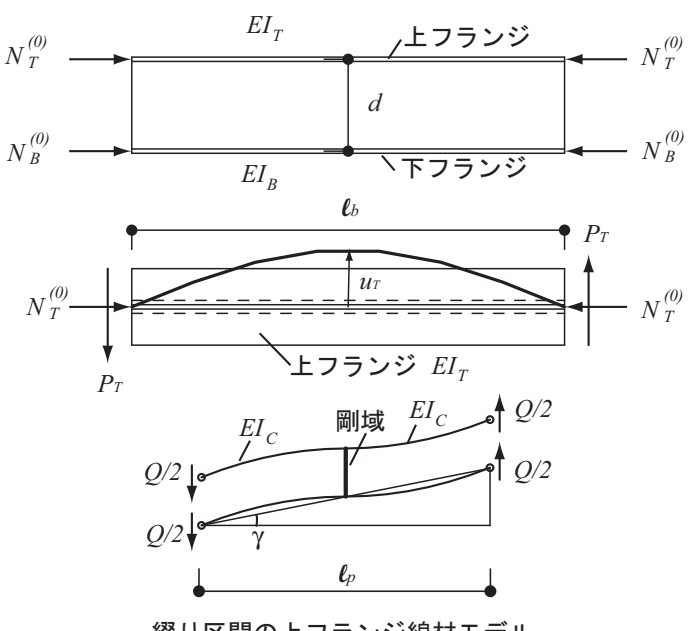

Fig.2 組立材上フランジ部のモデル

Table 1 高強度鋼の素材特性

\begin{tabular}{c|c|c|c|c}
\hline 鋼種 & 降伏点 & 引張強さ & 破断伸び & $\begin{array}{c}\text { 加工硬化 } \\
\text { 開始歪 } \\
\end{array}$ \\
& $\mathrm{N} / \mathrm{mm}^{2}$ & $\mathrm{~N} / \mathrm{mm}^{2}$ & $\%$ & $\%$ \\
\hline H-SA700A & 702 & 746 & 25.7 & 0.98 \\
H-SA700A & 772 & 812 & 25.9 & 1.01 \\
\hline 平均 & 737 & 779 & 25.8 & 1.00 \\
\hline
\end{tabular}

保持を仮定した弱軸曲げ抵抗が，個々の材が曲げ変形した曲率分だ け低下するものとして評価すればよい ${ }^{10)}$. 上フランジに横曲げが生 じると，構面外せん断力 $Q$ が次式の量だけ発生する.

$$
Q=N_{T}^{(0)} \cdot u_{T}^{\prime}
$$

このせん断力に対して, 溝形鋼の上フランジ部分（曲げ岡性が $E I_{c}$, 負担せん断力は $Q / 2$ と仮定する）の変形角 $\gamma$ は,

$$
\gamma=\frac{\frac{Q}{2} \cdot\left(\frac{\ell_{p}}{2}\right)^{3}}{3 \cdot E \cdot I_{c}} \cdot \frac{1}{\frac{\ell_{p}}{2}}=\frac{Q \cdot \ell_{p}^{2}}{24 \cdot E \cdot I_{c}}=\frac{N_{T}^{(0)} \cdot \ell_{p}^{2}}{24 \cdot E \cdot I_{c}} \cdot u_{T}^{\prime}
$$

したがって, この変形による曲げ抵抗低減分の曲率は, 次式となる

$$
\gamma^{\prime}=\frac{N_{T}^{(0)} \cdot \ell_{p}^{2}}{24 \cdot E \cdot I_{c}} \cdot u_{T}^{\prime \prime}
$$

この低減分を（2）式の釣り合い方程式に取り入れると, 


$$
\begin{aligned}
& {\left[E \cdot I_{T} \cdot\left(1-\frac{N_{T}^{(0)} \cdot \ell_{p}^{2}}{24 \cdot E \cdot I_{c}}\right) \cdot u_{T}^{\prime \prime}\right]^{\prime \prime}-\left[G \cdot J \cdot\left(\frac{u_{T}{ }^{\prime}-u_{B}{ }^{\prime}}{d^{2}}\right)\right]^{\prime}+\left[N_{T}^{(0)} \cdot u_{T}{ }^{\prime}\right]^{\prime}=0} \\
& {\left[E \cdot I_{B} \cdot\left(1-\frac{N_{B}^{(0)} \cdot \ell_{p}^{2}}{24 \cdot E \cdot I_{c}}\right) \cdot u_{B}^{\prime \prime}\right]^{\prime \prime}-\left[G \cdot J \cdot\left(\frac{u_{B}{ }^{\prime}-u_{T}{ }^{\prime}}{d^{2}}\right)\right]^{\prime}+\left[N_{B}^{(0)} \cdot u_{B}^{\prime}\right]^{\prime}=0}
\end{aligned}
$$

$(5 . a, b)$

さて，両端の支持条件が横曲げとねじりに対して単純支持条件を満 足する場合には，座屈変形は次式で与えられる.

$$
u_{T}=a_{T} \cdot \sin \left(\frac{\pi}{\ell_{b}} \cdot z\right), \quad u_{B}=a_{B} \cdot \sin \left(\frac{\pi}{\ell_{b}} \cdot z\right)
$$

ここに, $a_{T}, a_{B}$ は振幅, $\ell_{b}$ は座屈長さである.

初期合応力分布が材軸方向に一様であれば，仮想仕事の原理の式を 用いることなく, 直接に釣り合い方程式を連立させて座屈固有方程 式が得られる。上式を釣り合い方程式に代入し, 整理すると,

$$
\begin{aligned}
& {\left[N_{T}^{(0)}-\frac{\pi^{2} \cdot E \cdot I_{T}}{\ell_{b}^{2}} \cdot\left(1-\frac{N_{T}^{(0)} \cdot \ell_{p}{ }^{2}}{24 \cdot E \cdot I_{c}}\right)-\frac{G \cdot J}{d^{2}}\right] \cdot a_{T}+\frac{G \cdot J}{d^{2}} \cdot a_{B}=0} \\
& \frac{G \cdot J}{d^{2}} \cdot a_{T}+\left[N_{B}^{(0)}-\frac{\pi^{2} \cdot E \cdot I_{B}}{\ell_{b}^{2}} \cdot\left(1-\frac{N_{B}^{(0)} \cdot \ell_{p}{ }^{2}}{24 \cdot E \cdot I_{c}}\right)-\frac{G \cdot J}{d^{2}}\right] \cdot a_{B}=0
\end{aligned}
$$

$a_{T}, a_{B}$ が意味のある解を持つためには， $a_{T}, a_{B}$ の係数行列式が 0 と なる必要がある。これが次式の固有方程式である.

$$
\begin{aligned}
& \left\langle N_{T}^{(0)}-\frac{\pi^{2} \cdot E \cdot I_{T}}{\ell_{b}{ }^{2}} \cdot\left(1-\frac{N_{T}^{(0)}}{\frac{24 \cdot E \cdot I_{c}}{\ell_{p}^{2}}}\right)-\frac{G \cdot J}{d^{2}}\right) \cdot \\
& \left.N_{B}^{(0)}-\frac{\pi^{2} \cdot E \cdot I_{B}}{\ell_{b}{ }^{2}} \cdot\left(1-\frac{N_{B}^{(0)}}{\frac{24 \cdot E \cdot I_{c}}{\ell_{p}^{2}}}\right)-\frac{G \cdot J}{d^{2}}\right)-\left(\frac{G \cdot J}{d^{2}}\right)^{2}=0
\end{aligned}
$$

ほぼ H 形をした断面では弱軸曲げ岡性はフランジが支配的となる. $E I_{T}, E I_{B}$ に溝形鋼のフランジのみの断面性能を与えた場合と, 組立 材の弱軸曲げ岡性の半分を与えた場合, $E I_{C}$ に溝形鋼単材のフランジ のみの断面性能を与えた場合と溝形鋼単材の弱軸曲げ剛性の半分を 与えた場合とでは，いずれの場合でも横座屈耐力の差は大きくない. 後述するように, 中心圧縮の座屈耐力実験值との整合性は, 材の弱 軸曲げ剛性の半分を与えた場合が良好であったため, 本研究では, 組立材上下フランジの断面性能 $I_{T}, I_{B}$, 溝形鋼単材の上フランジの断 面性能 $I_{C}$ を次式のように与えることとした.

$$
I_{T}=I_{B}=\frac{I_{y}}{2}, \quad I_{c}=\frac{I_{y 1}}{2}
$$

ここに， $I_{y}$ は断面全体の弱軸断面 2 次モーメント, $I_{y 1}$ は溝形鋼単 材の弱軸断面 2 次モーメントである.

さて，(8）式を満足する $M^{(0)} ， N^{(0)}$ を座屈耐力としてそれぞれ $M_{e}, N_{e}$ と表すことにする.

(3.a,b) 式と（9.a,b）式を（8）式に代入して整理し， $M_{e}, N_{e}$ を用い て表すと, 最終的に座屈耐力相関関係式が次式のように得られる.

$$
\begin{aligned}
& \left\langle\left(\frac{N_{e}}{2}+\frac{M_{e}}{d}\right)-\frac{\pi^{2} \cdot E \cdot I_{y}}{2 \cdot \ell_{b}^{2}} \cdot\left(1-\frac{\frac{N_{e}}{2}+\frac{M_{e}}{d}}{\frac{12 \cdot E \cdot I_{y 1}}{\ell_{p}{ }^{2}}}\right)-\frac{G \cdot J}{d^{2}}\right) \\
& \left\langle\left(\frac{N_{e}}{2}-\frac{M_{e}}{d}\right)-\frac{\pi^{2} \cdot E \cdot I_{y}}{2 \cdot \ell_{b}^{2}} \cdot\left(1-\frac{\frac{N_{e}}{2}-\frac{M_{e}}{d}}{\frac{12 \cdot E \cdot I_{y 1}}{\ell_{p}{ }^{2}}}\right)-\frac{G \cdot J}{d^{2}}\right)-\left(\frac{G \cdot J}{d^{2}}\right)^{2}=0
\end{aligned}
$$

ちなみに, (10) 式に $M_{e}=0$ を代入して $N_{e}$ について解けば, 次式の 中心圧縮弾性座屈耐力評価式が得られる.

$$
\begin{aligned}
N_{e} & =2 \cdot \frac{\pi^{2} \cdot E \cdot I_{y}}{2 \cdot \ell_{b}^{2}} \cdot \frac{1}{1+\frac{\pi^{2} \cdot E \cdot I_{y}}{2 \cdot \ell_{b}{ }^{2}} \cdot \frac{\ell_{p}{ }^{2}}{12 \cdot E \cdot I_{y 1}}} \\
& =\alpha \cdot \frac{\pi^{2} \cdot E \cdot I_{y}}{\ell_{b}{ }^{2}} \ldots \ldots \ldots \ldots \ldots \ldots \ldots \ldots \ldots \ldots \ldots \ldots \ldots \ldots \ldots \ldots
\end{aligned}
$$

ここに， $\alpha$ は綴りによる弱軸曲げ抵抗の減少率である.

$$
\alpha=\frac{1}{1+\frac{\pi^{2} \cdot E \cdot I_{y}}{\ell_{b}^{2}} \cdot \frac{\ell_{p}^{2}}{24 \cdot E \cdot I_{y 1}}} .
$$

(10) 式に $N_{e}=0$ を代入して, $M_{e}$ について解けば目的の弾性横座屈曲 げ耐力評価式が次式のように得られる.

$$
M_{e}=\frac{\pi^{2} \cdot E \cdot I_{y}}{2 \cdot \ell_{b}{ }^{2}} \cdot \sqrt{1+2 \cdot \frac{G \cdot J}{d^{2}} \cdot \frac{2 \cdot \ell_{b}^{2}}{\pi^{2} \cdot E \cdot I_{y}}} \cdot \frac{d}{1+\frac{\pi^{2} \cdot E \cdot I_{y}}{2 \cdot \ell_{b}{ }^{2}} \cdot \frac{\ell_{p}{ }^{2}}{12 \cdot E \cdot I_{y 1}}}
$$

上式を整理し, 曲げモーメント勾配の効果をモーメント係数 $C$ で 考慮することにすると最終的には次式が得られる.

$$
\begin{aligned}
M_{e} & =C \cdot \alpha \cdot \sqrt{\frac{\pi^{2} \cdot E \cdot I_{y}}{\ell_{b}{ }^{2}} \cdot\left(\frac{\pi^{2} \cdot E \cdot I_{y} \cdot\left(\frac{d}{2}\right)^{2}}{\ell_{b}{ }^{2}}+G \cdot J\right)} \\
& =C \cdot \alpha \cdot \sqrt{\frac{\pi^{2} \cdot E \cdot I_{y}}{\ell_{b}{ }^{2}} \cdot\left(\frac{\pi^{2} \cdot E \cdot I_{w}}{\ell_{b}{ }^{2}}+G \cdot J\right)} \ldots \ldots \ldots .
\end{aligned}
$$

ここで， $I_{w}$ は曲げねじり定数に相当する量で次式で与えられる.

$$
I_{w}=I_{y} \cdot\left(\frac{d}{2}\right)^{2}
$$

Cは, モーメント係数で, 次式で近似できると仮定した.

$$
C=1.75+1.05 \cdot \frac{M_{2}}{M_{1}}+0.30 \cdot\left(\frac{M_{2}}{M_{1}}\right)^{2} \leq 2.3
$$

$M_{2}, M_{1}$ : 横補剛区間両端の曲げモーメントで, $\left(M_{2} / M_{1}\right)$ は複曲率 では正，単曲率では負で与える。

尚，最大耐力時にねじり角が大きくなることを想定し，面内曲率 のねじり角変形に及ぼす影響を考慮する場合は, (12.a) 式中において, $I_{y}$ を次式の $I_{y}^{*}$ とすればその影響を取り入れることができる ${ }^{12)-14)}$. 文 献 $15 〜 17$ にはその詳細な誘導過程が示されている. 


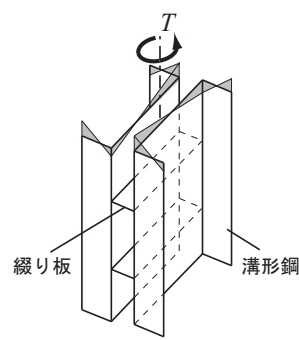

(a) そりに基因する面内直応力の ねじり抵抗

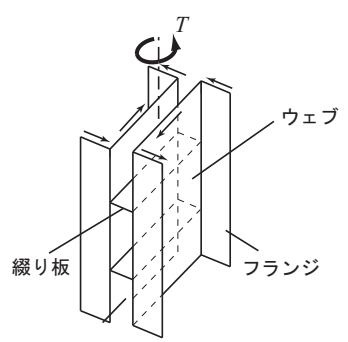

(b) 面内せん断応力による ねじり抵抗
Fig.3組立て材のねじり抵抗モデル

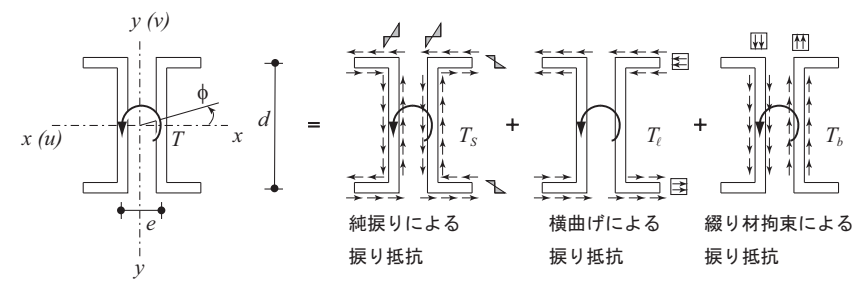

Fig.4 組立材断面に生じるねじり抵抗モーメント

$$
I_{y}^{*}=\frac{I_{y}}{1-\frac{I_{y}}{I_{x}}}
$$

ここに, $I_{x}:$ 組立材の強軸断面 2 次モーメント

\section{2 断面定数の算定式}

組立材を板材にモデル化し，そりに基因する面内直応力と，面内 せん断応力によるねじり抵抗の模式図を, Fig.3に示す.

緅り材を図のような板材に置換して考えると, 綴り材は, そりに 対してあまり抵抗しないこと, また, 溝形鋼ウェブのせん断変形を 拘束することが予想できる.

Fig.4 に組立材断面に生じる主要なねじり抵抗モーメントを示す.

上述の考察から, 従来考慮されていた純衫じり, 横曲げによるね じり抵抗に加えて, 綴り材で拘束することによって生じるねじり抵 抗を考虑して，断面定数を決定する.

\section{2.1 サンブナンねじり定数 $J$}

まず，綴り材拘束によるねじり抵抗について考える．Fig.5 に示す 綴り材拘束によって生じるウェブの偶力 $Q_{w}$ は, ウェブのせん断ひず みを $\gamma^{*}$, ウェブの断面積を $A_{w}$ とすると, 次の関係がある.

$$
\gamma^{*}=\frac{Q_{w}}{G \cdot A_{w}}
$$

ここで，綴り材幅 $w$ の領域は断面が大きくなるので剛域と仮定する と, 綴り区間 $\ell_{p}$ でのウェブの鉛直変形 $v$ は, 上式のせん断変形と溝 形鋼単材の曲げ変形との和で次式で表される.

$$
v=\frac{Q_{w}}{G \cdot A}\left(\ell_{p}-w\right)+\frac{Q_{w} \cdot\left(\ell_{p}-w\right)^{3}}{12 \cdot E \cdot I_{x 1}}
$$

また，区間のねじり角 $\phi$ と $v$ との間には，次式が成立する，
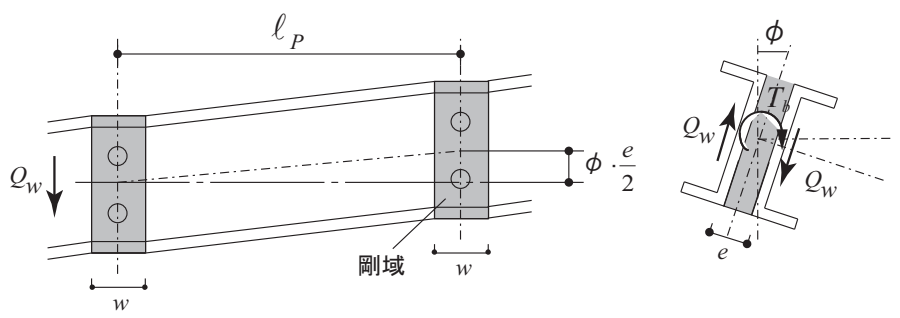

Fig.5 綴り材拘束によるねじり抵抗

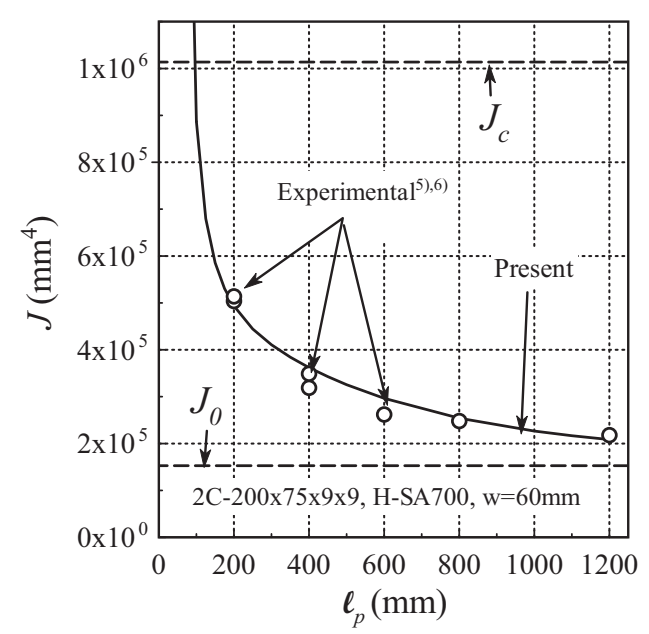

Fig.6 綴り材間隔のサンブナンねじり定数に及ぼす影響

$$
v=\phi \cdot \frac{e}{2}
$$

ここに, $\mathrm{e}$ は, 溝形鋼のウェブの板厚中心間距離である.

綴り材の拘束による抵抗モーメント $T_{b}$ は, 次式で求まる.

$$
T_{b}=Q_{w} \cdot e
$$

（14），(15）式からvを消去し， $Q_{w}$ について解き，（16）式に代入 すると, 次式が得られる.

$$
T_{b}=G \cdot \frac{\ell_{p}}{\ell_{p}-w} \cdot \frac{e^{2}}{\frac{2}{A_{w}}+\frac{G \cdot\left(\ell_{p}-w\right)^{2}}{6 \cdot E \cdot I_{x 1}}} \cdot \frac{\phi}{\ell_{p}}
$$

(17) 式から分かるように， $T_{b}$ は平均的なねじり率 $\phi / \ell_{p}$ に関係す るので, サンブナンねじり定数 $J$ に寄与する. また, 綴り材幅 $w$ の 区間を十分に剛と仮定すると，純ねじり抵抗モーメント $T_{s}$ は，綴り 位置以外の断面のサンブナンねじり定数 $J_{0}$ を用いて次式のように書 ける。

$$
T_{s}=G \cdot J_{0} \cdot \frac{\ell_{p}}{\ell_{p}-w} \cdot \frac{\phi}{\ell_{p}}
$$

よって, 組立材全体のサンブナンねじり定数 $J$ にるねじり 抵抗は, $T_{s}$ と $T_{b}$ の和となることから, 次式が得られる.

$$
G \cdot J \cdot \frac{\phi}{\ell_{p}}=T_{b}+T_{s}=G \cdot \frac{\ell_{p}}{\ell_{p}-w} \cdot\left(\frac{e^{2}}{\frac{2}{A_{w}}+\frac{G \cdot\left(\ell_{p}-w\right)^{2}}{6 \cdot E \cdot I_{\mathrm{r} 1}}}+J_{0}\right) \cdot \frac{\phi}{\ell_{p}} \text { (19) }
$$


Table 2 組立材の断面形状と断面性能

(a) 断面形状

\begin{tabular}{|c|c|c|c|c|c|}
\hline 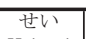 & 幅 & 板厚 & \begin{tabular}{l|} 
外径 \\
\end{tabular} & 綴り板厚 & 督り板幅 \\
\hline$H(\mathrm{~mm})$ & $b(\mathrm{~mm})$ & $t(\mathrm{~mm})$ & Ro $(\mathrm{mm})$ & $t_{p}(\mathrm{~mm})$ & $w(\mathrm{~mm})$ \\
\hline 200.2 & 75.16 & 9.05 & 31.67 & 9.05 & 60.00 \\
\hline \multicolumn{6}{|c|}{ (b) 溝形鋼の断面性能 } \\
\hline 断面積 & \multicolumn{2}{|c|}{$\begin{array}{c}\mathrm{x} \text { 軸回り } \\
\text { 断面2次モーメント }\end{array}$} & \multicolumn{2}{|c|}{\begin{tabular}{c|} 
y1軸回り \\
断面2次モーメント
\end{tabular}} & \begin{tabular}{|c|} 
ウェブ外面から \\
図心距離
\end{tabular} \\
\hline${ }^{A l}\left(\mathrm{~mm}^{2}\right)$ & \multicolumn{2}{|c|}{$I x I\left(\mathrm{~mm}^{4}\right)$} & \multicolumn{2}{|c|}{$I y l\left(\mathrm{~mm}^{4}\right)$} & $x_{o}(\mathrm{~mm})$ \\
\hline 2797 & \multicolumn{2}{|c|}{$1.488 \times 10^{7}$} & \multicolumn{2}{|c|}{$1.389 \times 10^{6}$} & 20.96 \\
\hline
\end{tabular}

(c) 組立材の断面性能

\begin{tabular}{|c|c|c|c|c|c|c|}
\hline \multirow{2}{*}{$\begin{array}{l}\text { 断面積 } \\
A\left(\mathrm{~mm}^{2}\right)\end{array}$} & \multirow{2}{*}{$\begin{array}{c}\mathrm{x} \text { 軸回り } \\
\text { 断面2次モーメント } \\
I x\left(\mathrm{~mm}^{4}\right)\end{array}$} & \multirow{2}{*}{$\begin{array}{c}\text { y軸回り } \\
\text { 断面2次モーメント } \\
I y\left(\mathrm{~mm}^{4}\right)\end{array}$} & \multicolumn{3}{|c|}{$\begin{array}{l}\text { サンブナンの } \\
\text { ねじり定数 }\end{array}$} & \multirow{2}{*}{\begin{tabular}{|c} 
曲げ \\
㸚じり定数 \\
$I_{w}\left(\mathrm{~mm}^{6}\right)$ \\
\end{tabular}} \\
\hline & & & 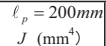 & $\begin{array}{c}\ell_{p}=400 \mathrm{~mm} \\
J\left(\mathrm{~mm}^{4}\right)\end{array}$ & $\begin{array}{c}\ell_{p}=800 \mathrm{~mm} \\
J\left(\mathrm{~mm}^{4}\right)\end{array}$ & \\
\hline 5595 & $2.975 \times 10^{7}$ & $6.411 \times 10^{6}$ & $4.587 \times 10^{5}$ & $3.430 \times 10^{5}$ & $2.489 \times 10^{5}$ & $5.856 \times 10^{10}$ \\
\hline
\end{tabular}

$e=t+t_{P}, A_{w}=\left(H-2 R_{0}\right) \cdot t$ という関係と, 上式から, 求める $J$ は, 次式のようになる。

$$
J=\frac{\ell_{p}}{\ell_{p}-w} \cdot\left(\frac{\frac{\left(t+t_{p}\right)^{2}}{\frac{2}{\left(H-2 \cdot R_{o}\right) \cdot t}+\frac{G \cdot\left(\ell_{p}-w\right)^{2}}{6 \cdot E \cdot I_{x 1}}}+J_{0}}{)}\right)
$$

ここに， $t_{p}$ は，綴り板厚であり， $J_{0}$ は，次式となる，

$$
J_{0}=\frac{2}{3} \cdot\left(2 \cdot\left(b-R_{o}\right)+\pi \cdot\left(R_{o}-\frac{t}{2}\right)+H-2 \cdot R_{o}\right) \cdot t^{3}
$$

（20.a）式は，綴りによって材軸方向に断面形が変化する材の，全体に ついてのサンブナンねじり定数の算定式であり, 綴り材間隔 $\ell_{p}$ と綴 り材幅 $w$ に依存する形になっている.

\subsection{2 曲げねじり定数 $I_{w}$}

2 つの溝形鋼の上フランジに生じる曲げモーメント $M_{f}$ は，その断 面 2 次モーメントが，組立材の弱軸断面 2 次モーメント $I_{v}$ のほぼ半 分であることから，上フランジの $\ell_{p}$ 区間の横変位を $u_{T}$ と表すと, $M_{f}$ は，次式で表される。このとき，綴り材による曲げ抵抗の減少は， 別途考慮されていることに留意する。

$$
M_{f}=-E \cdot\left(\frac{I_{y}}{2}\right) \cdot u_{T}^{\prime \prime}
$$

$\ell_{p}$ 区間のねじり角 $\phi$ と $u_{T}$ との関係は, 上下フランジの間隔を $d$ と すると，次式で表される.

$$
u_{T}=\phi \cdot \frac{d}{2} .
$$

曲げ $M_{f}$ により生じるせん断力 $Q_{f}$ は, 次式で求まる

$$
Q_{f}=-\frac{d M_{f}}{d z}
$$

フランジの横曲げによる抵抗力 $T_{\ell}$ は, 曲げねじり定数を用いた定義 式と (21)，(22)，（23) 式を用いて，次式のように整理できる.

$$
T_{\ell}=E \cdot I_{w} \cdot \phi^{\prime \prime \prime}=Q_{f} \cdot d=E \cdot I_{y} \cdot\left(\frac{d}{2}\right)^{2} \cdot \phi^{\prime \prime \prime}
$$

\begin{tabular}{|c|c|c|c|c|c|c|c|}
\hline & & Exp. & $\overline{\text { Exp. }}$ & Exp. & \multicolumn{2}{|c|}{ Cal. } & Cal. \\
\hline$\ell b$ & $\ell p$ & $N \mathrm{cr}$ & $\sigma \mathrm{cr}$ & $\sigma \mathrm{cr} / \sigma \mathrm{y}$ & $\mathrm{Ne}$ & $\mathrm{Ncr} / \mathrm{Ne}$ & $\alpha$ \\
\hline $\mathrm{mm}$ & $\mathrm{mm}$ & $\mathrm{kN}$ & $\mathrm{N} / \mathrm{mm} 2$ & - & $\mathrm{kN}$ & - & - \\
\hline 2940 & 200 & 1554 & 278 & 0.35 & 1488 & 1.04 & 0.991 \\
\hline 2940 & 400 & 1500 & 268 & 0.34 & 1450 & 1.03 & 0.966 \\
\hline 2940 & 600 & 1468 & 262 & 0.33 & 1391 & 1.06 & 0.927 \\
\hline 2940 & 1200 & 1318 & 236 & 0.30 & 1140 & 1.16 & 0.760 \\
\hline 2140 & 200 & 2800 & 500 & 0.63 & 2786 & 1.01 & 0.984 \\
\hline 2140 & 400 & 2897 & 518 & 0.65 & 2656 & 1.09 & 0.938 \\
\hline 2140 & 800 & 2584 & 462 & 0.58 & 2239 & 1.15 & 0.790 \\
\hline 1340 & 200 & 3736 & 668 & 0.84 & 6931 & 0.54 & 0.959 \\
\hline 1340 & 400 & 3862 & 690 & 0.87 & 6179 & 0.63 & 0.855 \\
\hline
\end{tabular}

従って， $I_{w}$ に相当する量は，(12.b) 式と同様となる.

$$
I_{w}=I_{y} \cdot\left(\frac{d}{2}\right)^{2}
$$

Table 3 中心圧縮試験結果との比較

上式から曲げねじり定数 $I_{w}$ は，綴り材間隔に影響されないことが分 かる.

\section{3 断面定数算定式の傾向と低減係数の妥当性}

\section{3. 1 サンブナンねじり定数算定式の妥当性}

組立材のサンブナン据り定数 $J$ の算定式の妥当性を検討するため に，Table 2 に示寸断面の組立材について綴り材間隔 $\ell_{p}$ を $100 \mathrm{~mm} \mathrm{\sim}$ $1200 \mathrm{~mm}$ と変化させた場合について $J$ を求め, 文献 5,6 の河野ら の実験結果と比較した。

結果を Fig.6に示す. Fig.6は，綴り材間隔 $\ell_{p}$ と組立材全体のサン ブナンねじり定数 $J$ の関係を，河野らの実験值を○印で，(20.a）式 の算定值を実線で示す，尚，同図には，綴り位置及びそれ以外の位 置の断面における綴り材の拘束を考慮しない時のサンブナンねじり 定数 $J_{c}, J_{0}$ の值を示している.

断面定数算定式は, 綴り材間隔 $\ell_{p} 200 \mathrm{~mm} \sim 1200 \mathrm{~mm}$ の範囲で良好 に実験值と一致することが分かる。

\section{3.2 弱軸曲げ抵抗の減少率の妥当性}

組立材の経りによる弱軸曲げ抵抗の低減係数 $\alpha$ の算定式の妥当性 を検討するため,（11.a）式と文献 4 で河野らの行った中心圧縮座屈 に関する実験結果と比較した。試験体の形状，断面性能は,前述の試 験体と同様で Table 2 に示したものである. 比較結果を Table 3 に示寸. Table 3 には, 座屈長さ $\ell_{b}$, 綴り材間隔 $\ell_{p}$, 最大軸力 $N_{c r}$, 最大軸方 向応力 $\sigma_{c r}$, 降伏応力で無次元化した最大軸方向応力 $\sigma_{c r} / \sigma_{y}, \quad(11$ a) 式でもとめた, 弾性座屈軸力 $N_{e}, N_{e}$ と実験值 $N_{c r}$ との比と綴りに よる弱軸曲げ抵抗の減少率 $\alpha$ の值を示す，綴り材間隔 $\ell_{p}$ が, $600 \mathrm{~mm}$ 以下で，圧縮応力が降伏応力の 6 割の範囲では，（11.a）式から得ら れた $N_{e}$ と実験值の最大軸力とが非常に良好に一致することから， $\ell_{p}$ が $600 \mathrm{~mm}$ 以下であれば，弾性座屈耐力算定式における弱軸曲げ抵抗 低減係数で綴り材間隔の影響を評価できることが分かる。

\section{3. $3 M_{e}-N_{e}$ 弾性座屈耐力相関関係式の形状と傾向}

Table 2 に示寸断面の組立材について，支点間距離 $\ell_{b}$ を $5 \mathrm{~m}$ ，綴り 材間隔 $\ell_{p}$ を $200 \mathrm{~mm}, 400 \mathrm{~mm}$ とした場合について, (10) 式の $M_{e}-N_{e}$ 座 屈耐力相関関係式を求めた結果を Fig.7 に示す. 尚, 同図には文献 1 の実験值も示す。 


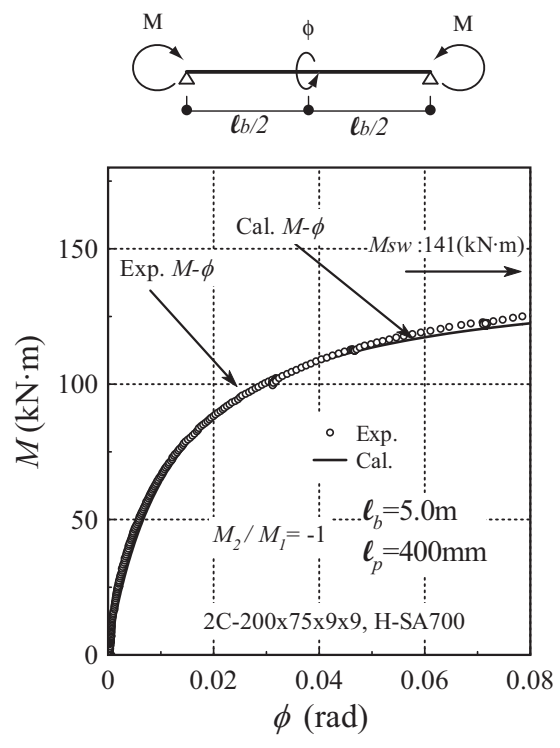

(a) M- $\phi$ 関係

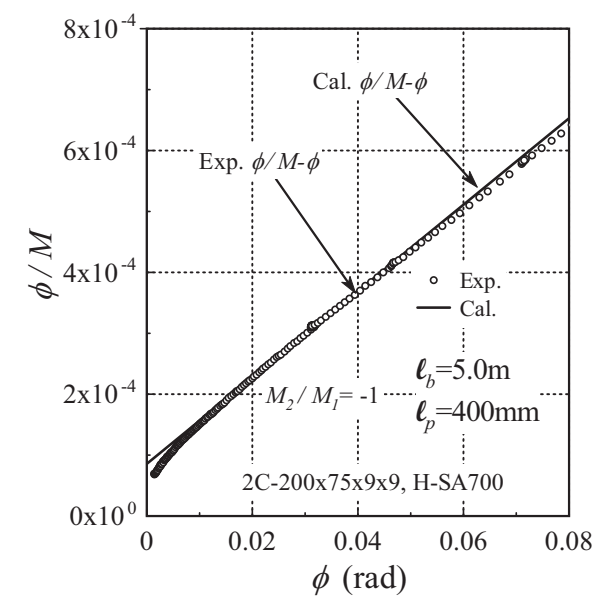

(b) $(\phi / M)-\phi$ 関係

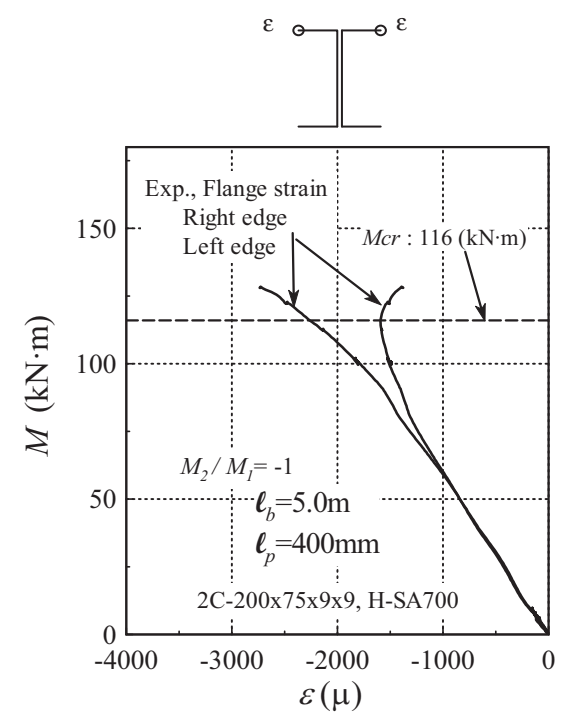

(c) $\mathrm{M}-\varepsilon$ 関係

Fig.8サウスウェルの方法による弾性横座屈耐力の推定

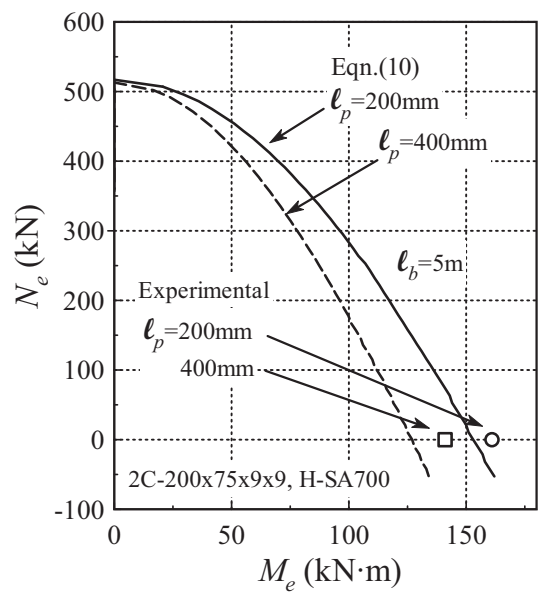

Fig.7 $\quad M_{e}-N_{e}$ 弹性座屈耐力相関関係 $\ell_{b}=5 \mathrm{~m}, \ell_{p}=200 \mathrm{~mm}, 400 \mathrm{~mm}$

この図から, 組立材の $M_{e}-N_{e}$ 弾性座屈耐力相関関係式は, 曲げ卓越 時に綴り間隔の影響が大きくなる形式の，外に凸で放物曲線状にひ らいた曲線となることがわかる. (12.a) 式の弾性横座屈曲げ耐力式と (11.a) 式の中心圧縮弹性座屈耐力式は, 1 つの (10) 式の $M_{e}-N_{e}$ 弹性座 屈耐力相関関係式から導出されおり, 両式の断面定数等は互いに関 連している. 曲げ抵抗低減係数の妥当性は，中心圧縮試験により明 らかにされたので, 残された課題は曲げ卓越時に綴り材間隔の影響 が大きくなるであろうサンブナンねじり定数と曲げねじり定数の妥 当性を明らかにすることになる. 次節では，これらの断面定数を有 する曲げ耐力算定式を横座屈試験結果との比較から検討する.

\section{4. 弾性横座屈曲げ耐力算定式と実験結果との比較}

\section{1 比較対象とする実験値について}

実験值で求める弾性横座屈耐力として，1) 上フランジの左右端面 のひずみの進行が反転する時点での曲げモーメント $\left.M_{c r}, 2\right)$ 最大曲
げモーメント $\left.M_{\max }, 3\right)$ ねじり角が発散する時点での曲げモーメント $M_{s w}$, が考えられる.

等曲げ横座屈実験の結果（試験区間 $\ell_{b}=5 \mathrm{~m}$, 綴り材間隔 $\ell_{p}=400$ mm）を Fig. 8 に示す. (a) に曲げモーメント $M$ と中央断面のねじり 角 $\phi$ の関係，(b)に $(\phi / M)$ と $\phi$ との関係，(c)に $\mathrm{M}$ と上フランジ 左右端面の材軸方向ひずみ $\varepsilon$ の関係を示す。この図から分かるよう に，今回取扱う幅広断面で，強軸回りに対する弱軸回りの断面 2 次 モーメントの比が大きい場合では, 横座屈現象による耐力低下は生 じにくくなる ${ }^{12-14)}$. 大きな稀じり角が生じフランジ端面のひずみが 反転しても耐力は上昇する。ささら荷重を上げると大きなねじり角 によって部分的に塑性化が生じ, 求めた最大耐力は非弾性の効果が 入った值となる．片曲げ下ではこの傾向がさらに強くなる．

弾性横座屈曲げ耐力式（横座屈固有值）と比較するのであるから， 実験值は部分的な材料非線形の効果を除去した極限值である必要が ある.さらにやや非弾性領域の支持点距離の短い結果についても利 用できるようになれば，広い範囲で式の妥当性が検証できることに なる。

そこで，本研究では大きなねじり角が生じた時点を対象とし，ね じり角の発散する時点での曲げモーメント $M_{s w}$ を取り上げ，横座屈 基準曲げ耐力と呼んで比較対象の実験值と寸る。この $M_{s w}$ は付録に 示すサウスウェルの方法 ${ }^{10)}$ で算定する. 弾性範囲のモーメント $M$ と䃿じり角 $\phi$ の関係の実験值から補外して最小 2 乗法で極限值を求 めるので，材料非線形の効果はほとんど除去できるが，補外のため 誤差が大きくなる危険性を持っている.

Fig.8(a),(b) の $M-\phi, \quad(\phi / M)-\phi$ 関係には，○で実験值を，実線で サウスウェルの方法による関数曲線を示している. 関数あてはめは 良好なので，弾性範囲における，ねじり角無限大の時の曲げモーメ ントを推定可能であることがわかる. 


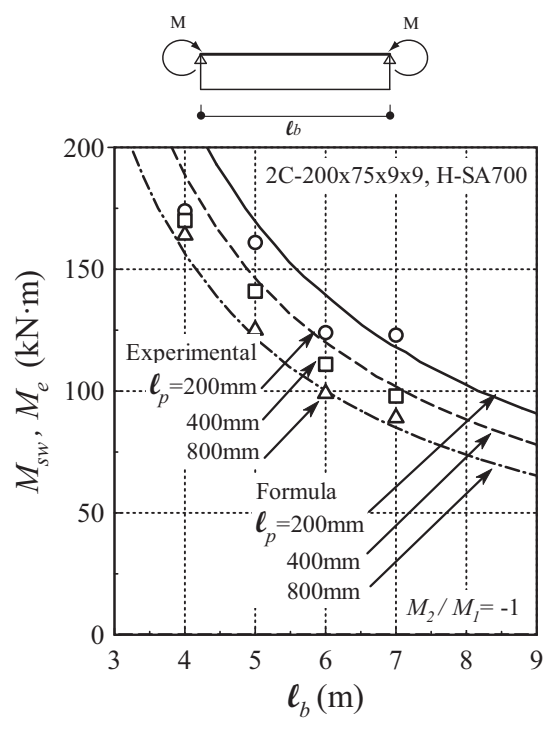

(a) 等曲げ

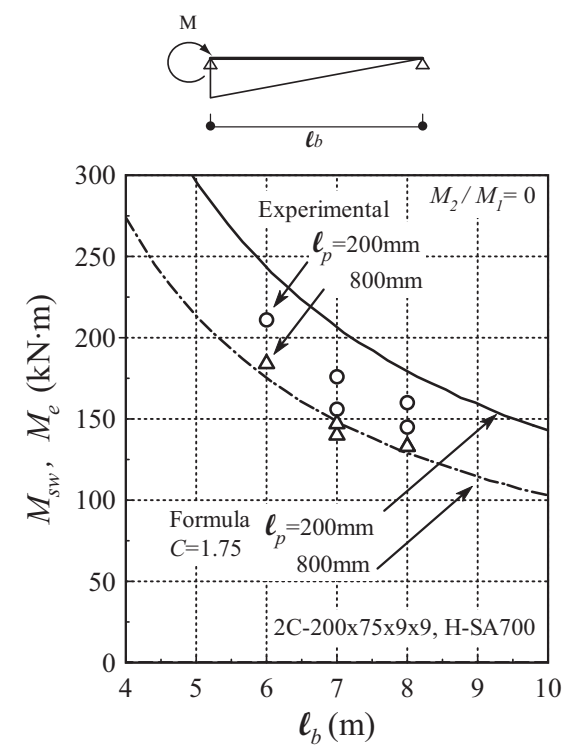

(b) 片曲げ

Fig.9 弾性横座屈耐力算定式との比較

Table 4 横座屈試験結果との比較

(a) 等曲げ

\begin{tabular}{|c|c|c|c|c|c|c|c|c|c|}
\hline $\begin{array}{c}\ell b \\
\mathrm{~m}\end{array}$ & $\begin{array}{l}\ell \mathrm{p} \\
\mathrm{mm}\end{array}$ & $\begin{array}{c}\text { Exp. } \\
M \text { cr } \\
\mathrm{kN} \cdot \mathrm{m}\end{array}$ & $\begin{array}{c}\text { Exp. } \\
M \max \\
\mathrm{kN} \cdot \mathrm{m}\end{array}$ & $\begin{array}{c}\text { Exp. } \\
M \mathrm{sw} \\
\mathrm{kN} \cdot \mathrm{m}\end{array}$ & $\begin{array}{c}M \mathrm{e} \\
\mathrm{kN} \cdot \mathrm{m}\end{array}$ & $\begin{array}{c}\mathrm{Cal} \\
M \mathrm{cr} / M \mathrm{e}\end{array}$ & $M \mathrm{sw} / M \mathrm{e}$ & $\begin{array}{c}\text { Cal. } \\
\alpha\end{array}$ & Specimen \\
\hline 7.0 & 800 & 63 & 76 & 89 & 85 & 0.74 & 1.05 & 0.976 & HS3L \\
\hline 7.0 & 400 & 67 & 78 & 98 & 102 & 0.66 & 0.96 & 0.994 & HS3L \\
\hline 7.0 & 200 & 83 & 93 & 122 & 118 & 0.70 & 1.03 & 0.998 & HS3L \\
\hline 6.0 & 800 & 67 & 84 & 99 & 100 & 0.67 & 0.99 & 0.967 & HS3L \\
\hline 6.0 & 400 & 79 & 94 & 111 & 120 & 0.66 & 0.93 & 0.992 & HS3L \\
\hline 6.0 & 200 & 97 & 103 & 124 & 139 & 0.70 & 0.89 & 0.998 & HS3L \\
\hline 5.0 & 800 & 99 & 114 & 125 & 122 & 0.81 & 1.02 & 0.954 & HS4 \\
\hline 5.0 & 400 & 116 & 128 & 141 & 147 & 0.79 & 0.96 & 0.988 & HS4 \\
\hline 5.0 & 200 & 141 & 146 & 161 & 170 & 0.83 & 0.95 & 0.997 & HS4 \\
\hline 4.0 & 800 & 138 & 149 & 164 & 157 & 0.88 & 1.04 & 0.929 & HS4 \\
\hline 4.0 & 400 & 145 & 151 & 170 & 189 & 0.77 & 0.90 & 0.981 & HS4 \\
\hline 4.0 & 200 & 154 & 154 & 174 & 218 & 0.71 & 0.80 & 0.995 & HS4 \\
\hline 3.0 & 800 & (154) & 154 & 177 & 218 & $(0.71)$ & 0.81 & 0.881 & HS4 \\
\hline 3.0 & 400 & (164) & 164 & 185 & 268 & $(0.61)$ & 0.69 & 0.967 & HS4 \\
\hline 3.0 & 200 & (172) & 172 & 187 & 307 & $(0.56)$ & 0.61 & 0.992 & HS4 \\
\hline
\end{tabular}

\section{2 実験值との比較}

文献 1 の等曲げ・片曲げ下の実験結果と提案する弾性横座屈曲げ 耐力算定式 (12.a-d) 及び (20.a) 式との比較を行った.

高強度鋼組立材の等曲げ横座屈実験（実験 I）の比較結果を

Fig.9(a), Table 4(a) に, 片曲げ横座屈実験（実験 II）の比較結果を Fig.9(b), Table 4(b) に示す.

実験 I は，試験区間長さ $\ell_{b}$ を $7.0 \mathrm{~m}, 6.0 \mathrm{~m}, 5.0 \mathrm{~m}, 4.0 \mathrm{~m}, 3.0 \mathrm{~m}$ と したものについて，それぞれ，綴り材間隔 $\ell_{p}$ を $800 \mathrm{~mm}, 400 \mathrm{~mm}$, $200 \mathrm{~mm}$ と変化させている.

実験 II は，試験区間長さ $\ell_{b}$ を $8.0 \mathrm{~m} ， 7.0 \mathrm{~m} ， 6.0 \mathrm{~m} ， 4.5 \mathrm{~m}$ としたも のについて, それぞれ, 綴り材間隔 $\ell_{p}$ を $800 \mathrm{~mm}, 200 \mathrm{~mm}$ と変化させ, $\ell_{b}$ が $4.5 \mathrm{~m}$ については $\ell_{p}$ を $200 \mathrm{~mm}$ としている．実験 II は複数回実 験を行った。

Table 4(a) には, 実験 I で求めた横座屈基準曲げ耐力 $M_{s w}$ と $C=1.0$ (等 曲げ $\left.M_{2} / M_{1}=-1\right)$ として, 弾性横座屈曲げ耐力評価式 (12.a-d) 及び (20. a) 式から求めた值 $M_{e}$ および評価値 $M_{e}$ に対する実験值 $M_{s w}$ の比, 弱 軸曲げ抵抗の減少率 $\alpha$ を示す. Table 4(b) には, 実験 II で求めた横座 屈基準曲げ耐力 $M_{s w}$ と $C=1.75$ (片曲げ $M_{2} / M_{1}=0$ ) とした同様の評価 (b) 片曲げ

\begin{tabular}{|c|c|c|c|c|c|c|c|c|c|}
\hline $\begin{array}{l}\ell \mathrm{b} \\
\mathrm{m}\end{array}$ & $\begin{array}{l}\ell \mathrm{p} \\
\mathrm{mm}\end{array}$ & $\begin{array}{c}\text { Exp. } \\
M \mathrm{cr} \\
\mathrm{kN} \cdot \mathrm{m}\end{array}$ & $\begin{array}{c}\text { Exp. } \\
M \max \\
\mathrm{kN} \cdot \mathrm{m}\end{array}$ & $\begin{array}{c}\text { Exp. } \\
M \mathrm{sw} \\
\mathrm{kN} \cdot \mathrm{m}\end{array}$ & $\begin{array}{c}M \mathrm{e} \\
\mathrm{kN} \cdot \mathrm{m}\end{array}$ & $\begin{array}{c}\text { Cal. } \\
M \mathrm{cr} / M \mathrm{e}\end{array}$ & $M \mathrm{sw} / M \mathrm{e}$ & $\begin{array}{c}\text { Cal. } \\
a\end{array}$ & Specimen \\
\hline 8.0 & 800 & 98 & 111 & 133 & 129 & 0.76 & 1.03 & 0.981 & $\begin{array}{l}\text { HS3L } \\
\end{array}$ \\
\hline 8.0 & 800 & 86 & 105 & 133 & 129 & 0.67 & 1.03 & 0.981 & HS3L \\
\hline 8.0 & 200 & 98 & 133 & 160 & 180 & 0.54 & 0.89 & 0.999 & HS3L \\
\hline 8.0 & 200 & 101 & 114 & 145 & 180 & 0.56 & 0.81 & 0.999 & HS3L \\
\hline 7.0 & 800 & 103 & 124 & 140 & 149 & 0.69 & 0.94 & 0.976 & HS3L \\
\hline 7.0 & 800 & 98 & 119 & 147 & 149 & 0.66 & 0.99 & 0.976 & HS3L \\
\hline 7.0 & 200 & 102 & 126 & 156 & 207 & 0.49 & 0.75 & 0.998 & HS3L \\
\hline 7.0 & 200 & 122 & 135 & 176 & 207 & 0.59 & 0.85 & 0.998 & HS3L \\
\hline 6.0 & 800 & 123 & 134 & 184 & 175 & 0.70 & 1.05 & 0.967 & HS3L \\
\hline 6.0 & 200 & 145 & 146 & 211 & 243 & 0.60 & 0.87 & 0.998 & HS3L \\
\hline 4.5 & 200 & (120) & 120 & & 334 & $(0.36)$ & - & 0.996 & HS3L \\
\hline
\end{tabular}

值等を示す.

また，参考のために同表には，上フランジの左右端面のひずみの 進行が反転する時点での曲げモーメント $M_{c r}$, 最大曲げモーメント $M_{\text {max }}$ も併せて示している. 尚, Table 4(a,b) での ( ) 内の数值は, 載荷中, ひずみが弾性限界に達したため, 上フランジの左右端面のひずみの 進行が反転する前に実験を中止しており， $M_{c r}$ の值は，この值以上と なることを示している.

Fig.9(a)には，等曲げ下において，綴り材間隔 $\ell_{p}$ が $200 \mathrm{~mm}$,

$400 \mathrm{~mm}, 800 \mathrm{~mm}$, 試験区間長さ $\ell_{b}$ を $3 \mathrm{~m} \sim 9 \mathrm{~m}$ と変化させた場合の評 価值 $M_{e}$ と実験值 $M_{\mathrm{sw}}$ （横座屈基準曲げ耐力）を，また, Fig.9(b) には,

片曲げ下において，綴り材間隔 $\ell_{p}$ が $200 \mathrm{~mm} ， 800 \mathrm{~mm}$ ，試験区間長 さ $\ell_{b}$ を $4 \mathrm{~m} \sim 10 \mathrm{~m}$ と変化させた場合の評価值 $M_{e}$ と実験值 $M_{s w}$ を示す. これら結果から，以下のことがわかる.

1）綴り材間隔を大きくすると，横座屈基準曲げ耐力は低下する. 綴り材間隔の横座屈基準曲げ耐力に及ぼす影響は比較的大き い.

2) 等曲げにおける評価値は，横座屈基準曲げ耐力の実験值と支点 間距離 $4 \mathrm{~m}$ 以下を除き，ほぼ一致する。

3) 評価式における，綴りによる弱軸曲げ抵抗の減少率の值は, 
0.99 0.93 程度であったことから, 綴り材間隔を短くすることに よる弾性横座屈耐力の上昇は主にサンブナンねじり定数が大き くなることに基因する.

4) 片曲げにおける評価值は, 横座屈基準曲げ耐力の実験值と比べ, 綴り材間隔 $800 \mathrm{~mm}$ でほぼ一致し，綴り材間隔 $200 \mathrm{~mm}$ で $20 \%$ 程度の差が生じるものの，綴り材間隔の影響を良好に表す。

5) 従って, 支持点間距離が $4 \mathrm{~m}$ 以下でかつ綴り材間隔が $200 \mathrm{~mm}$ 800mm 程度であれば, 算定式で弾性横座屈耐力を算定すれば, 2 割以内の誤差で, 評価ができる.ただし，片曲げ下において は過大評価になりうることに注意を要する.

\section{5. まとめ}

本論文では，高強度鋼を用いた乾式組立材について，組立材の弱 軸曲げ抵抗の低減率, サンブナンねじり剛性, 曲げねじり剛性の算 定式を用いた曲げ耐力評価式を提案し, 経り材間隔を変化させた等 曲げ, 片曲げの加力での横座屈耐力実験結果と, 弾性曲げ耐力算定 式との比較を行った.

得られた知見は, 以下のように要約できる.

\section{○算定式誘導過程から}

1) サンブナンねじり定数は, 綴り材間隔と綴り材幅に依存する 形になる一方, 曲げねじり定数は, 綴り材間隔に依存しない.

2 ) $M_{e}-N_{e}$ 弾性座屈耐力相関関係式は, 曲げ卓越時に綴り間隔の影 響が大きくなる形式で, 外に凸で放物曲線状にひらいた曲線と なる。

\section{○ねじり実験, 中心圧縮実験との比較から}

3 ）サンブナンねじり定数算定式は, 綴り材間隔 $200 \mathrm{~mm} \sim 1200 \mathrm{~mm}$ の範囲で良好に実験值と一致する.

4）綴り材間隔が $600 \mathrm{~mm}$ 以下であれば，弾性座屈耐力評価式にお ける弱軸曲げ抵抗の低減率で綴り材間隔の影響を良好に評価で き, 中心圧縮弾性座屈荷重を良好な精度で評価できる。

\section{○横座屈実験との比較から}

5 ）片曲げ下においては過大評価傾向にあるが，支持点間距離が $4 \mathrm{~m}$ 以下でかつ綴り材間隔が $200 \mathrm{~mm} \sim 800 \mathrm{~mm}$ 程度であれば, 評 価式で弾性横座屈耐力を算定すれば，2 割以内の誤差で, 評価 ができる。

6 ) 材軸方向に断面形状が変化する部材のサンブナンねじり定数 の算定式と弾性横座屈耐力の評価式は, 実験結果を良好に表し ており, 工学上妥当である.

\section{謝辞}

本研究は，社団法人日本鉄鋼連盟「鋼構造研究·教育助成事業」の 助成金を受けて実施しました。論文発表にあたり，給付頂いた同連 盟には深謝申し上げます。研究実施に際し，井上一朗教授 ( 岡山理 科大学), 吹田啓一郎教授 (京都大学) 河野昭彦教授 (九州大学), 津田惠吾教授 ( 北九州市立大学) のご指導を頂きました。 データ整 理には，広島工業大学 $2008 \cdot 2009$ 年度玉井研究室卒論生諸君，同 大学院生 三好行則君の多大な協力を得た。ここに記し, 感謝の 意を表します.

\section{参考文献}

1) 玉井宏章, 高松隆夫, 松尾彰 : 高強度鋼組立材の弾性横座屈性状に関する 研究，鋼構造年次論文報告集，第 17 巻, pp.549-556, 2009.11 .

2）玉井宏章，高松隆夫，松尾彰：建築構造用高強度 $780 \mathrm{~N} / \mathrm{mm} 2$ 鋼材 (H-SA700) を用いた乾式組立部材の設計法 その 4 ，その 5 横座屈実験の結果, 日本建築学会大会学術講演梗概集, 構造・C-1, pp.365-368, 2009.8.

3) 玉井宏章, 高松隆夫, 山西央朗, 松尾彰: 高強度鋼組立材の横座屈性状に 関する研究 (その 2 横座屈試験結果) 広島工業大学紀要 研究編, 第 44 巻, pp.229-239, 2010.2.

4) 喬崎雲, 河野昭彦, 津田惠吾, 城戸將江 : 柱の圧縮耐力に関寸る実験的 研究 建築構造用高強度 $780 \mathrm{~N} / \mathrm{mm} 2$ 鋼材 (H-SA700) を用いた乾式組立 部材の設計法 その 1 , 日本建築学会大会学術講演梗概集, 構造 C-1, pp.597-598,2009.8

5) 李泰洙, 喬崎雲, 河野昭彦, 津田惠吾, 城戸將江 : 組立部材の捩り剛性に 関する実験的研究 建築構造用高強度 $780 \mathrm{~N} / \mathrm{mm} 2$ 鋼材 (H-SA700) を用いた 乾式組立部材の設計法 その 2 , 日本建築学会大会学術講演梗概集, 構造 C-1, pp.599-600,2009.8.

6) 喬崎雲, 河野昭彦, 津田惠吾, 城戸將江, 吉海伸祐, 李泰洙, 窪寺弘顕 : 超高強度乾式組立材の衫じり剛性に関する実験的研究, 日本建築学会研究 報告九州支部，構造系，第 48 号·1，pp.365-368，2009.3.

7) 木村 慧, 吹田啓一郎, 佐藤篤司, 井上一朗 : 摩擦ダンパー接合によ る乾式柱梁接合部の性能検証実験 建築構造用高強度 $780 \mathrm{~N} / \mathrm{mm} 2$ 鋼材 （H-SA700）を用いた乾式組立部材の設計法 その 6, 日本建築学会大会学 術講演梗概集, 構造 C-1, pp.607-608,2009.8.

8) 佐藤篤司, 木村 慧, 吹田啓一郎, 井上一朗 : 建築構造用高強度鋼材 H-SA700A を用いた柱梁材を弾性に留める乾式接合法の開発, 日本建築学 会構造系論文集，第 74 巻，第 646 号, pp.2355-2363， 2009.12.

9) 岩本卓麻, 安村光春, 向出静司, 多田元英, 甲津功夫, 一戸康生, 沼田俊之, 多賀謙蔵, 桑原進, 佐々木正道 : $1000 \mathrm{~N}$ 級鋼 $(950 \mathrm{~N} / \mathrm{mm} 2)$ の建築構造物への 適用性について（その $11 \mathrm{H}$ 形断面柱・梁の局部座屈性状に関寸る実験的 検討), 日本建築学会大会学術講演梗概集, 構造 C-1, pp.615-616,2008.8.

10) Timoshenko. S.P., Gere. J.M : Theory of Elastic Stability, Second Edition, Mc Graw-Hill, pp.135-142, pp.190-192, 1961.

11）鈴木敏郎：H 形鋼部材の横座屈応力度について（はりの横座屈に関する研 究), 日本建築学会論文報告集, 第229号, pp43-189, 1975.3.

12）伊藤文人：構造安定論, IV はりの横座屈, 技報堂, pp.112-134, 1989.2.

13) 福本唀士：新体系土木工学 9 , 構造物の座屈・安定解析, 技報堂, pp.160-181, 1982.9 .

14) 土木学会 : 鋼構造シリーズ 12, 座屈設計ガイドライン, 改訂第 2 版 [2005 年版 ], 丸善, pp.110-111，2005.10。

15) 坂井藤一 : 薄肉開断面部材の弾性安定基礎方程式の統一的誘導, 土木学 会論文集，221 号，pp.1-15，1974.1.

16) 西野文雄, 倉方慶夫, 長谷川彰夫, 奥村敏恵 : 軸力と曲げおよびねじり を受ける薄肉断面部材, 土木学会論文集, 225 号, pp.1-15, 1974.5 .

17) 討議者 : 西野文雄, 倉方慶夫, 長谷川彰夫 / 回答者 : 坂井藤一: 薄肉断 面部材の弾性安定基礎方程式の統一的誘導, 土木学会論文集, 238 号, pp.111-113, 1975.6 .

\section{付録 サウスウエルの方法}

サウスウェルの方法 ${ }^{10)}$ を解説する。この方法は, 㸚じり角と曲げモーメン 卜関係を用いて次式の関数当てはめをおこない, 補外することによって, 実験 では得られない, ねじり角無限大の時の曲げモーメントを求めようとするもの である。

基本のなる関数は，ねじり角を曲げモーメントで割った值を $\mathrm{y}$ 軸，ねじり角 を $\mathrm{x}$ 軸で整理したとき, 傾き $1 / M_{s w}, \mathrm{y}$ 切片 $a$ の直線式である. 


$$
\frac{\phi}{M}=\frac{1}{M_{s w}} \cdot \phi+a
$$

式変形すると,

$$
\phi=\frac{a \cdot M_{s w}}{\frac{M_{s w}}{M}-1}
$$

となるので, $M=M_{s w}$ のとき, $\phi$ は発散する. すなわち, $M=M_{s w}$ がねじれ角無 限大の時の曲げモーメントとなっている.
さて, 横座屈実験の結果から, 最小 2 乗法を用いて (A-1) 式の直線式の傾き と $\mathrm{y}$ 切片を求めると, Fig.8(a),(b) となる. 曲げモーメント $M$ とねじり角 $\phi$ の関 係， $(\phi / M)$ と $\phi$ との関係では，丸で実験值を，実線でサウスウェルの方法に よる関数曲線を示している．関数あてはめは良好である．補外なので，真の解 との誤差が出やすいという久点はあるものの, 弾性範囲の実験結果から, 材料 が弾性を維持し続けた場合における, ねじり角無限大の時の曲げモーメントが 求められるという利点がある.

（2010年 6 月 7 日原稿受理，2010年10月 6 日採用決定） 